\title{
Towards Improved Industrial Relations in Public Higher Learning Insti- tutions of Ethiopia: The Case of Ambo University
}

\author{
G. S. Ogato \\ Department of Rural Development and Agricultural Extension, Institute of Cooperatives and Development Studies, Ambo Uni- \\ versity, Ethiopia
}

\begin{abstract}
The general objective of the study was to assess the problems and prospects of industrial relations of employees of Ambo University and propose strategic measures for better future. The findings of the study will serve as baseline information for researchers who are interested to conduct further research on issues of industrial relations in Ambo University and other public higher learning institutions in Ethiopia and Africa . Furthermore, the strategic recommendations to be forwarded as a final output of the study will enable employees of Ambo University and its management or employer to properly understand major problems and prospects of industrial relations and jointly search for sustainable solutions of the issues identified. The proposed study relied on both secondary and primary data types. The study employed both purposive and simple random sampling techniques. The proposed study employed a comprehensive data collection method whereby both secondary and primary methods of data collection methods were employed to address the objectives of the study. The first methodological step was a comprehensive analysis of the existing literature in order to obtain both theoretical insights and secondary data. The second methodological step was collection of primary data from primary sources. Accordingly, data were collected with the help of structured questionnaire, field observation, and focus group discussion. The qualitative data captured through focus group discussion and field observation were transcribed, interpreted, and analyzed in the form of descriptions and narrations. Data collected through structured questionnaire were analyzed with the help of SPSS (Version 20). Accordingly, Simple descriptive statistics like frequencies and percentages were employed. Promoting good governance and democracy in all management levels of Ambo University, creating favorable working environment and environment of good will and mutual cooperation among employees, and encouraging employees to use modern technologies like ICTs in service delivery are some of the strategic measures proposed in this study to improve the industrial relations of employees of Ambo University.
\end{abstract}

Key Words: Academic, Ambo University, community service, Industrial relations, research

\section{Introduction}

Industrial relations cover all such relationships that a business enterprise maintains with various sections of the society such as workers, state customers, and public who come into its contact. In other words, it is the study of the interactions among industry, its employees and the governments that oversee them. Moreover, it is the study of the various institutions and organizations that are formed as a result of these interactions, such as labour unions and business unions. Some scholars also define Industrial relations as a field of study that concentrates on employment relationships between management and workers. As part of the social sciences, industrial relations attempts to understand relationships through industry employment and its institutions. Some scholars also note the three perspectives of industrial relations: pluralist, unitarist, and radical. In a nutshell, industri- al relations may be defined as "the employeremployee relationships covered specifically under collective bargaining and industrial relation laws. It also encompasses other organizations such as governments, institutions, and organizations that directly or indirectly regulate the industrial relations system. In this study, industrial relations refer to the relationship between Ambo University as employer and its employees (academic staff and administrative staff).

Corresponding author: G. S. Ogato Department of Rural Development and Agricultural Extension, Institute of Cooperatives and Development Studies, Ambo University, Ethiopia Email:gemechushale2005@yahoo.com

$\circledast_{1}$ This article is distributed under the terms of the Creative Commons Attribution License, which permits unrestricted use and redistribution provided that the original author and source are credited. 
Ambo University (AU) is one of the oldest and historical higher learning institutions in Ethiopia. It is found in the West Showa Zone of the Oromia National Regional State, and is located about $110 \mathrm{~km}$ West of Addis Ababa. The current Ambo University was established in 1939 as an agricultural school. It was known with different names before it has assumed its present name. Among others, it was named, Ambo Agriculture and Forestry Secondary School in 1958; Ambo Institute of Agriculture in 1967 and Ambo Junior College of Agriculture in 1974. In 2003, it was affiliated to Jimma University and named Jimma University - Ambo College and in 2008 it became autonomous and named Ambo University College. Since 2009, it has become a fullfledged higher learning institution - Ambo University (Ambo University, 2015).

In addition to educational and research activities, the university conducts short term training, offers outreach services, and provides consultancy services. With regard to research and community services, the University has been conducting pertinent researches and outreach programs. The University is working with public, private and civil society organizations.

The current human resource profile of the university indicates a total of 850 members of academic staff (765 males and 85 females); and a total of 1471 members of administration staff (531 males and 940 females) (Ambo University, 2015).

Ambo University has been contributing much for promoting sustainable development at local, regional, and national level through educational and research activities, short term training, o outreach services, and consultancy services. While its great contribution is commendable, little attention was given to its industrial relations by researchers in the field of industrial relations. In other words, problems and prospects of industrial relations of employees of Ambo University were not explored, management responses to these issues were not studied, and industrial relations strategy in the organization was not developed. Scholars in the field of industrial relations contend that many problems lie central to the study of industrial relations. However, they attest that learning about these problems is a good place to start gaining a better understanding of how the modern world's economic interrelations function. Hence, the contribution of our study for filling the aforementioned research and information gap is a reality. To this end, our study proposes to assess challenges and prospects of industrial relations of employees of Ambo University.

The approaches underpinning this study are combination of psychological, sociological, and human relations approach. The study adopted the psy- chological approach as it assessed the perception of employees regarding issues of industrial relations like workplace disputes, organizational low profits, limited good will and mutual cooperation, and limited promotion of democracy through different levels of organization. Employees' perception on the reaction of the management to the aforementioned issues also demanded the adoption of psychological approach. The study also adopted sociological approach as it dealt with the interaction among social actors in Ambo University. Finally, human relations approach was also adopted due to the fact that it was concerned with the interpersonal relationships among persons in the organization.

The study had both general and specific objectives. The general objective of the study is to assess the challenges and prospects of industrial relations of employees of Ambo University and propose strategic measures for better future. The specific objectives of the study are:

1. To analyze the employees perceptions on challenges and prospects of industrial relations of employees of Ambo University; 2. To analyze employees' perceptions on the reaction of Ambo University to minimize workplace disputes, increase profits, create an environment of goodwill and mutual cooperation, and promote democracy throughout all levels of the organization; and

3. To propose possible solutions to solve challenges of industrial relations of employees in Ambo University.

The study answered the following research questions:

1. What are the critical problems of industrial relations of employees of Ambo University?

2. What are the prospects of industrial relations of employees of Ambo University?

3. How do employees of Ambo University perceive about problems and prospects of industrial relations in their organization?

4. How do employees of Ambo University perceive about the reaction of Ambo University to minimize workplace disputes, increase profits, and create an environment of goodwill and mutual cooperation? and

5. What are the possible solutions to solve issues of industrial relations of employees of Ambo University?

\section{Research Methodology}

This section deals with description of the study area, types and sources of data, sampling methods and procedures, methods of data collection, data measurement and methods of data analysis. 
Description of the Study Area: Ambo University is located in Ambo town. Ambo area is known for its different natural resources including the abundant resources and attractive scenery. Its perennial rivers including Huluka (which is originated in Dandi district at a place called Danbal), Taltale, Boji, BurkaTiko (Chopho) etc are of crucial importance (Ambo Town Administration Office, 2013).The mean annual temperature of the area over 30 years (1981-2010) is about $18.64^{\circ} \mathrm{C}$. The mean annual rainfall of the town over 30 years $(1981-2010)$ is about $968.7 \mathrm{~mm}$. The highest rainfall concentration occurs from June to September (UN-HABITAT, 2008,Shanmugham \&Tekele, 2011; Ambo Town Administration Office, 2013).

Research Design, Data Types and Sources: A research design is a logical and valuable way of looking at the world. In this study, the researcheremployed a mixed research design methodology. The basic reason for the researcher to adopt a mixed research design methodology is that it assists in understanding complex data and gives a more complete and comprehensive account of the enquiry. The quantitative research was in the form of close ended questions in a questionnaire and it provided numerical evidence and allowed statistical analysis. Open-ended questions, in the questionnaires, key informant interview, field observation and focus group discussion constituted the qualitative part of this research.

With regard to data types, the proposed study relied on both secondary and primary data types.The secondary sources for the secondary data were reports of Ambo University, reports of Ministry of Education, national and regional industrial relations policies and strategies, and robust published materials (books, journal articles, reports of national and international organizations, and internet sources) on industrial relations. The primary sources for the primary data were employees and top management of Ambo University.

Sample Size and Sampling Techniques: The study employed purposive and simple random sampling techniques in two steps. First, purposive sam- pling technique was employed to select Ambo University since the purpose of the study is to assess the problems and prospects of industrial relations of employees of Ambo University and propose strategic measures for its improvement. Next, respondents for questionnaire administration were selected with the help of simple random sampling technique to select representative number of employees from the total population. Respondents to participate in focus group discussion were also selected purposively from employees of Ambo University.

The sample size for employee survey was determined based on the total number of employees in Ambo University. Accordingly, the sample size for collecting primary data from employees of Ambo University for the purpose of this study was determined by using the following formula (Yemane, 1967):

$$
\mathrm{n}=\frac{\mathrm{N}}{1+\mathrm{N}(\mathrm{e})^{2}}
$$

Where;

$\mathrm{n}=$ designates the sample size the study uses;

$\mathrm{N}=$ designates total number of households

$\mathrm{e}=$ designates maximum variability or margin of error $9 \%$;

$1=$ designates the probability of the event occurring.

Therefore;

$$
\mathrm{n}=\frac{\mathrm{N}}{1+\mathrm{N}(\mathrm{e})^{2}}
$$

Sample size determination aims at selecting part of the population from which information will be drawn to form conclusions about the entire population. By applying the above formula:

$$
n=\frac{2321}{1+2321(.09)^{2}}
$$

$\mathrm{n}=116$ employees

The sample size of each stratum (academic staff and administrative staff) is determined using the proportional method of sample size distribution as follows (see table 1 also):

1. Sample size for Administrative Staff $=\frac{1471}{2321} \times 116=74$ administrative Staff members

2. Sample size for Academic Staff $=\frac{850}{2321} \times 116=$ 42 academic staff members

Table 1: Employees' Sample Design

\begin{tabular}{llll}
\hline No & Staff Status & $\begin{array}{l}\text { Target Population } \\
\text { (Employees of Ambo University) }\end{array}$ & Sample Employees \\
\hline 1 & Administrative Staff & 1471 & 74 \\
2 & Academic Staff & 850 & 42 \\
3 & Total & 2321 & 116 \\
\hline
\end{tabular}

Source: Personnel Office, Ambo University, 2015. 
Methods of Data Collection: This study employed a comprehensive data collection method whereby both secondary and primary methods of data collection methods were employed to address the objectives of the study.

The first methodological step was a comprehensive analysis of the existing literature in order to obtain both theoretical insights and secondary data. Review themes include: concepts of industrial relations, issues of industrial relations of employees in service organizations, and management responses to issues of industrial relations of employees in service organizations.

The second methodological step was collection of primary data from primary sources. Accordingly, data were collected with the help of structured questionnaire (SQ), focus group discussion (FGD) field observation, and semi-structured interview as described hereunder.

1. Structured Employees' questionnaire: A structured questionnaire(SQ) was designed, pretested and distributed to 116 employees of Ambo University to analyze the employees' perceptions on issues of industrial relations of employees of Ambo University, and to analyze employees' perceptions on the reaction of Ambo University's management to minimize workplace disputes, increase profits, create an environment of goodwill and mutual cooperation, and promote democracy throughout all levels of the organization. To this end, respondents were randomly selected from administrative staff members and academic staff members of the organization and questionnaire in English and Amharic were distributed to them based on their level of understanding.

2. Focus Group Discussion: Focus group discussion (FGD) was also employed to collect data from different focal groups (administrative staff members and academic staff members). Participants of the focus group discussion were employees of the organization who have very good information about the current status of industrial relations in Ambo University. A total of four focus group discussions (two focus groups from each stratum) were made and each focus group consisted of 10 persons and the discussion in each group took about 30 minutes to 60 minutes. The checklist for the focus group discussion included: How do you perceive issues of industrial relations in your organization? How do you perceive the reaction of Ambo University to minimize workplace disputes, increase profits, and create an environment of goodwill and mutual cooperation? What must be done to overcome problems of industrial relations of employees in Ambo University?

3. Semi-structured Interview: Semi-structured interview (SSI) was also employed to collect primary qualitative data from top management level (Administrative and Development VicePresident Office) in Ambo University. Accordingly, in-depth interview was made with the aforementioned top management level of the University with the help of interview checklist.

4. Field Observation: field observation was employed as complementary method to questionnaire survey. Accordingly, some aspects of industrial relations of employees and management reactions on industrial relations across different strata (administrative staff and academic staff ) were observed.

Data Measurements: The study measured data through two measurements. Accordingly, nominal, and ordinal measures were employed to measure the attitudinal position and perception of employees regarding industrial relations of employees in Ambo University. Accordingly, nominal measure (yes or no questions) were employed to understand the position of respondents on the issues under investigation. Moreover, five level likert scales (ordinal measure) were employed to measure the perception of respondents on the issues under investigation.

Methods of Data Analysis: With regard to data analysis, both qualitative and quantitative methods of data analysis were employed. The qualitative data captured through focus group discussion, and field observation were transcribed, interpreted, and analyzed in the form of descriptions and narrations. Both quantitative data collected through secondary method of data collection and primary data collected from primary sources through questionnaire survey were analyzed in computer with the help of Microsoft excel. Accordingly, simple descriptive statistics like frequencies and, percentages were employed. The results of the analyzed data were presented with the help of bar graphs, pie charts, and tables.

\section{Results}

\section{Demographic Profile of Respondents}

This section describes the age composition of respondents, sex of respondents, marital status of respondents, education level of respondents, ethnic composition of respondents and religious composition of respondents.

1. Age Composition of Respondents: $65.5 \%$ $(n=76)$ respondents were within the age range of $31-50$ years of age while $31.9 \%(n=37)$ and $2.6 \%$ 
$(n=3)$ were within the age range of $18-30$ and greater than 51 respectively. This indicates that majority of the respondents were within the age of 31-50 years of age at the time of interview.

2. Sex of Respondents: $62.1 \%(n=72)$ of respondents were males while $37.9 \%(n=44)$ of them were females. This indicates that majority of the respondents were females.

3. Marital Status of Respondents: $68.1 \%(n=79)$ of respondents from the employees of Ambo University were married while $29.3 \%(n=34), 1.7 \%$ $(n=2)$, and $0.9 \%(n=1)$ of them were single, divorced and widow respectively at the time of interview.

4. Ethnicity of Respondents: $81 \%(n=94)$ of the respondents were from Oromo ethnic group. $16.4 \%(n=19), 1.7 \%(n=2)$, and ) $0.9 \%(n=1)$ of the respondents were from Amhara, Other ethnic group, and Tigre. This indicates that the majority of the respondents were from Oromo ethnic group.

5. Religious Composition of Respondents: $42.2 \%$ $(n=49)$ and $38.8 \%(n=45)$ of the respondents were from Protestant Christianity and Orthodox Christianity respectively. $13.8 \% \quad(n=16)$, and
$5.2 \%(n=6)$ of the respondents were from Muslim and "Wakefata" religious group respectively.

6. Education Level of Respondents: 63.8\% ( $n=74)$ of respondents were with university education (BSc/BA) level. 18.1\% ( $n=21), 13.8 \%(n=16)$, and $4.3 \%(n=5)$ of the respondents were with secondary/college education, MSc/MA education, and Primary education level respectively. This indicates that the majority of respondents were with university education (BSc/BA) level at the time of interview.

\section{Employees' Perceptions on Problems of Industrial Relations of Employees of Ambo University}

Respondents from Ambo University were asked to idfentify issues of industrial relations in their organization. $56.9 \%$ of the respondents voted for limitted good will of employees and mutual cooperation among employees as a problem of industrial relations in Ambo University. This was followed by $18.1 \%, 15.5 \%$ and $9.5 \%$ of respondents who voted for limitted promotion of democracy in all levels of the organization, low profits from academic, research, and community services, and work place disputes (See figure 1).

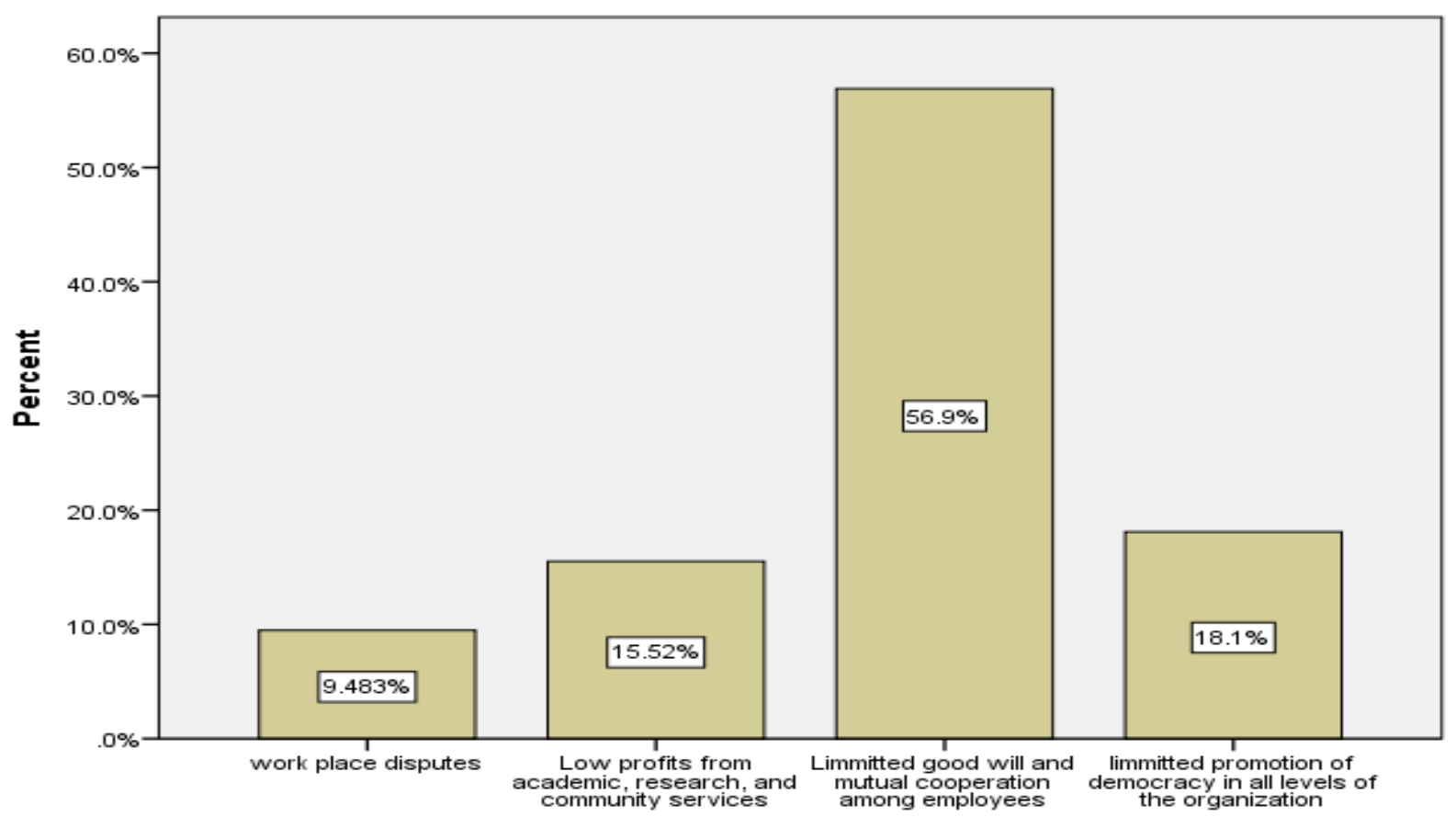

Figure 1: Issues of industrial relations in Ambo University 
Respondents were further asked to rate the extent of issues of industrial relations in their organization. The analysis of extent of each issue is presented hereunder.

Extent of Work Place Disputes: Respondents were asked to rate extent of workplace disputes in their organization. $60.3 \%(n=70)$ of the respondents voted for moderate extent of workplace disputes. $19.8 \%(n=23), 9.5 \%(n=11), 9.5 \%(n=11)$, and $0.9 \%$ $(n=1)$ of the respondents voted for low, high, very high, and very low extent of workplace disputes respectively (see table 2). This implies that majority of the respondents percive that the extent of workplace disputes in Ambo University is moderate.

Table 2. Perceived Extent of Workplace Disputes in Ambo University

\begin{tabular}{lll}
\hline Extent & Count & Percentage \\
\hline Very high & 11 & 9.5 \\
High & 11 & 9.5 \\
Moderate & 70 & 60.3 \\
Low & 23 & 19.8 \\
Very low & 1 & 0.9 \\
Total & 116 & 100 \\
\hline
\end{tabular}

Source: Survey, 2015

Extent of Organizational Profits from Academic, Research, and Community Services: Respondents were asked to rate extent of organizational profits from academic, research, and community services. $60.3 \%(n=70)$ of the respondents voted for moderate extent of organizational profits from academic, research, and community services. 15.5\% $(\mathrm{n}=18)$, $10.3 \%(n=12), 8.6 \%(n=10)$ and $5.2 \%(n=6)$ of the respondents voted for low, high, very high and very low organizational profits from academic, research, and community services respectively (see table 3 ). This implies that majority of the respondents percive that the extent of organizational profits from academic, research, and community services in Ambo University is moderate.

Table 3. Extent of Organizational Profits from Academic, Research, and Community Services

\begin{tabular}{lll}
\hline Extent & Count & Percentage \\
\hline Very high & 10 & 8.6 \\
High & 12 & 10.3 \\
Moderate & 70 & 60.3 \\
Low & 18 & 15.5 \\
Very low & 6 & 5.2 \\
Total & 116 & 100 \\
\hline
\end{tabular}

Source: Survey, 2015

Extent of Good Will and Mutual Cooperation: Respondents were asked to rate the extent of good will of employees and mutual cooperation among employees in Ambo University. 65.5\% (n=76) of the respondents voted for moderate extent of good will of employees and mutual cooperation among employees in Ambo University. 16.4\% ( $n=19), 14.4 \%(n=17)$, $1.7 \%(n=2)$, and $1.7 \%(n=2)$ of the respondents voted for high, low, very high, and very low extents of good will of employees and mutual cooperation among employees in their organization respectively (see table 4). This implies that majority of the respondents percive that the extent of good will of employees and mutual cooperation among employees in Ambo University is moderate. 
Table 4. Perceived Extent of good will and mutual cooperation among employees in Ambo University

\begin{tabular}{lll}
\hline Extent & Count & Percentage \\
\hline Very high & 2 & 1.7 \\
High & 19 & 16.4 \\
Moderate & 76 & 65.5 \\
Low & 17 & 14.7 \\
Very low & 2 & 1.7 \\
Total & 116 & 100 \\
\hline
\end{tabular}

Source: Survey, 2015

Extent of Promotion of Democracy in All Management Levels: Respondents were asked to rate extent of promotion of democracy through all management levels in their organization. 62.9\% $(n=73)$ of the respondents voted for moderate extent of promotion of democracy in all management levels of Ambo University. 25\% ( $n=29), 6.9 \%(n=8), 4.3 \%$ $(n=5)$, and $0.9 \%(n=1)$ of the respondents voted for low, very low, high, and very high extent of promotion of democracy in all management levels of Ambo University (see table 5). This implies that majority of the respondents percive that the extent of promotion of democracy in all management levels in Ambo University is moderate.

Table 5. Perceived Extent of Promotion of Democracy in All Management Levels

\begin{tabular}{lll}
\hline Extent & Count & Percentage \\
\hline Very high & 1 & 0.9 \\
High & 5 & 4.3 \\
Moderate & 73 & 62.9 \\
Low & 29 & 25 \\
Very low & 8 & 6.9 \\
Total & 116 & 100 \\
\hline
\end{tabular}

Source: Survey, 2015

\section{Employees' Perceptions on the Reaction of Ambo University's Management to Problems of Indus- trial Relations of Employees}

Respondents were asked to confirm whether the current management of Ambo University reacts to issues of industrial relations or not. The analysis of the respondents' perceptions on current management's reaction to each issue of industrial relations are presented hereunder.

1. Current Management's Reaction to Workplace Disputes: Respondents were asked to confirm whether the current management of Ambo University reacts to workplace disputes or not. $81 \%(n=94)$ of the respondents responded to yes answer while only $19 \%(n=22)$ of the respondents responded to no answer. This indicates that the majority of the respond- ents agree that the current management of Ambo University positively reacts to deal with work place disputes. Respondents were further asked to rate the extent of current management's reaction to minimize workplace disputes in their organization. $74.7 \%$ $(n=71)$ of the respondents voted for moderate extent of current management's reaction to minimize workplace disputes in their organization. $13.7 \%$ $(n=13), 6.3 \%(n=6), 3.2 \%(n=3)$, and $2.1 \%(n=2)$ of respondents voted for high, low, very high, and very low extent respectively of current management's reaction to minimize workplace dispute in their organization (see figure 2). This implies that majority of the respondents percive that the extent of current management's reaction to minimize workplace disputes in Ambo University is moderate. 


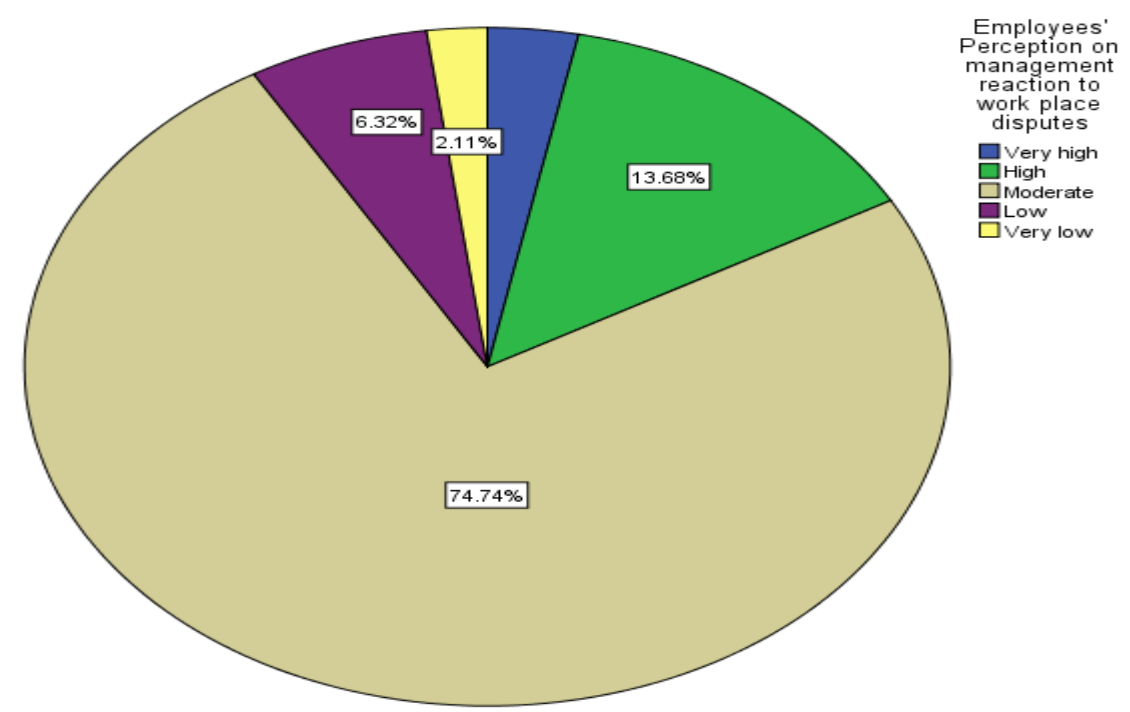

Figure 2: Percieved Extent of Current Management Reaction to Minimize Work Place Disputes in Ambo University

2. Current Management's Reaction to Increase Organizational Profits from Academic, Research, and Community Services: Respondents were asked to confirm whether the current management of Ambo University reacts to increase organizational profits from academic, research, and community services or not. $76.7 \%(n=89)$ of the respondents responded to yes answer while $23.3 \%(n=27)$ of them responded to no answer. This indicates that the majority of the respondents agree that the current management of Ambo University positively reacts to increase organizational profits from academic, research, and community services.

Respondents were further asked to rate the extent of current management's reaction to increase organizational profits from academic, research, and community services. $80.9 \% \quad(n=72)$ of the respondents voted for moderate extent of current management's reaction to increase organizational profits from academic, research, and community services. 9\% $(n=8), 4.5 \%(n=4), 3.4 \%(n=3)$, and $2.2 \%(n=2)$ of respondents voted for high, low, very high, and very low extent respectively of current management's reaction to increase organizational profits from academic, research, and communty services (see figure 3). This implies that majority of the respondents percive that the extent of current management's reaction to increase organizational profits from academic, research, and communty services in Ambo University is moderate.

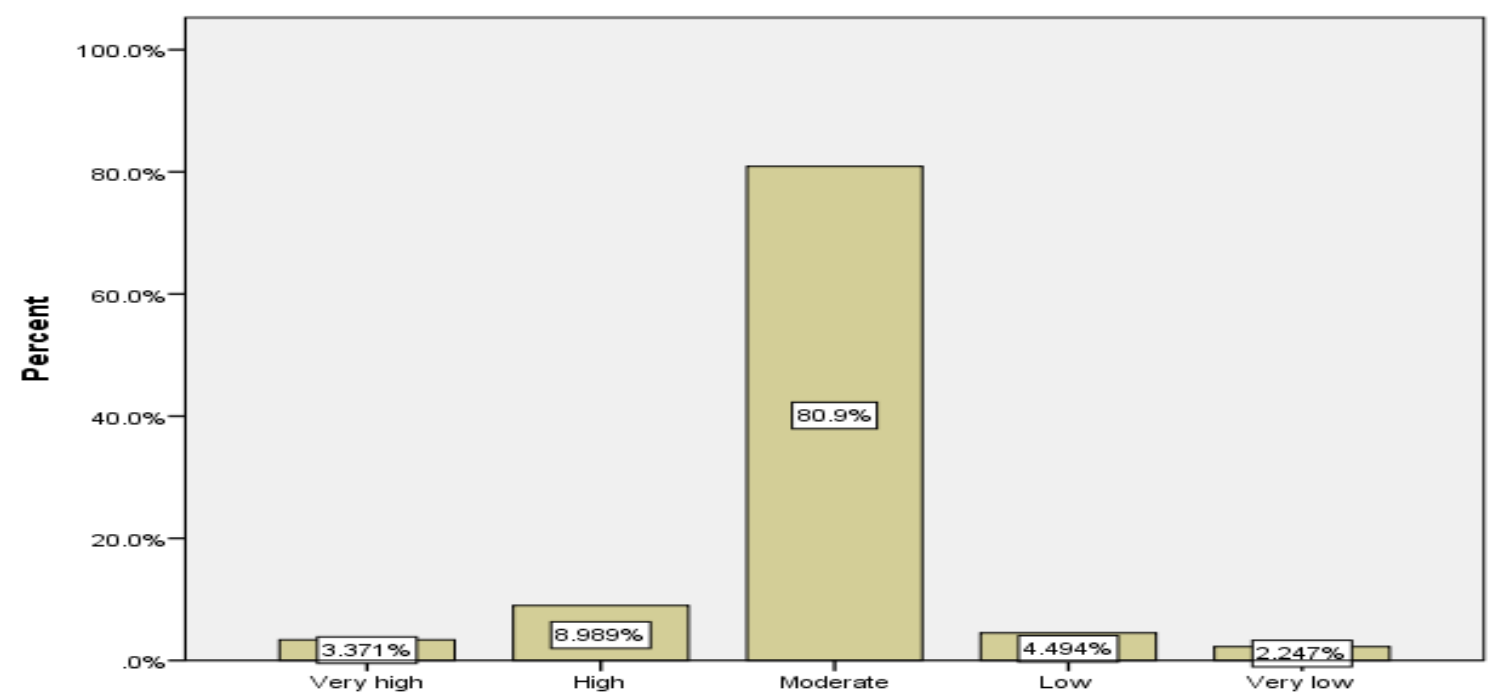

Figure 3: Percieved Extent of Current Management Reaction to Increase Organizational Profits from Academic, Research, and Community Services 
3. Current Management's Reaction to Create Environment of Good Will of Employees and Mutual Cooperation among Employees: Respondents were asked to confirm whether the current management of Ambo Plant Protection Research Center reacts to create environment of good will of employees and mutual cooperation among employees or not. $75.9 \%$ $(n=88)$ of the respondents responded to yes answer while $24.1 \%(n=28)$ of them responded to no answer. This indicates that the majority of the respondents agree that the current management of Ambo University positively reacts to create environment of good will of employees and mutual cooperation among employees.

Respondents were further asked to rate extent of current management's reaction to create environment of good will of employees and mutual cooperation among employees. $71.6 \%(n=63)$ of the respondents voted for moderate extent of current management's reaction to create environment of good will of employees and mutual cooperation among employees in their organization. 13.6\% $(\mathrm{n}=12), 8 \%$ $(n=7), \quad 4.5 \% \quad(n=4)$, and $2.3 \% \quad(n=2)$ of the respondents voted for high, low, very low, and very high extent respectively of current management's reaction to create environment of good will of employees and mutual cooperation among employees in their organization (see table 6). This implies that majority of the respondents percive that the extent of current management's reaction to create environment of good Will of employees and mutual cooperation among employees in Ambo University is moderate.

Table 6. Extent of Current Management's Reaction to Create Environment of Good Will and Mutual Cooperation

\begin{tabular}{lll}
\hline Extent & Count & Percentage \\
\hline Very High & 2 & 2.3 \\
High & 12 & 13.6 \\
Moderate & 63 & 71.6 \\
Low & 7 & 8 \\
Very Low & 4 & 4.5 \\
Total & 88 & 100 \\
\hline Source: Survey, 2015 & &
\end{tabular}

Source: Survey, 2015

Current Management's Reaction to Promote Democracy in All Management Levels: Respondents were asked to confirm whether the current management of Ambo University reacts to promote democracy in all management levels or not. $79.3 \%$ $(\mathrm{n}=92)$ of the respondents responded to yes answer while $20.7 \%(n=24)$ of them responded to no answer. This indicates that majority of the respondents agree that the current management of Ambo University positively reacts to promote democracy in all management levels.

Respondents were further asked to rate extent of current management's reaction to promote democracy in all management levels of their organization. $61.3 \%(n=57)$ of the respondents voted for moderate extent of current management's reaction to promote democracy in all management levels of the organization. $15.1 \%(n=14), 11.8 \%(n=11), 8.6 \%$ $(n=8)$, and $3.2 \%(n=3)$ of the respondents voted for high, low, very low, and very high extent respectively of current management's reaction to promote democracy in all management levels of the organization (see table 7). This implies that majority of the respondents percive that the extent of current management's reaction to promote in all management levels of their organization is moderate.

Table 7. Extent of Current Management's Reaction to Promote Democracy through All Management Levels of the organization

\begin{tabular}{lll}
\hline Extent & Count & Percentage \\
\hline Very High & 3 & 3.2 \\
High & 14 & 15.1 \\
Moderate & 57 & 61.3 \\
Low & 11 & 11.8 \\
Very Low & 8 & 8.6 \\
Total & 93 & 100 \\
\hline
\end{tabular}

Source: Survey, 2015 


\section{Possible Solutions to Overcome Problems of In- dustrial Relations of Employees}

A total of four focus group discussions (two focus groups from each stratum) were made and each focus group consisted of 10 persons and the discussion in each group took about 30-60 minutes. The promising results of the administered focus group discussions were the suggestions provided through these focus group discussions. The results of the four focus group discussions were similar and summarized for each issue of industrial relations of employees hereunder.

Employees' suggestions to reduce work place disputes in Ambo University

Participants of the focus group discussions suggested the following strategic measures to reduce work place disputes in Ambo University:

- The principles of good governance and democratic leadership should be more practiced in Ambo University;

- The employees should be more treated equally irrespective of their religion, gender, other sociocultural factors;

- Cooperation and tolerance among employees should be promoted;

- Comprehensive studies should be undertaken to assess work place disputes and sustainable solutions of the same in Ambo University; and

- Employees should be trained on university's rules and regulations;

Employees' suggestions to increase the profit of Ambo University from its academic, research and community services

Participants of the focus group discussions suggested the following strategic measures to increase the profit of Ambo University from its academic, research and community services:

- Income generating activities should be established and expanded;

- Strong partnerships and collaborations should be promoted on community-based business and entrepreneurial ideas and activities;

- Linkage with local, national, and international organizations should be strengthened;

- Work quality in academic, research, and community services should be improved;

- Employees' right should be protected and hardworking employees should be rewarded;

- Academic staff members of the University should be motivated to develop and implement research and development projects; and
- The University should develop income generating policy and strategy to serve research and development communities more elegantly;

Employees' suggestions to increase good will of employees and mutual cooperation among employees

Participants of the focus group discussions suggested the following strategic measures to increase good will of employees and mutual cooperation among employees in Ambo University:

- Education and training should be provided to employees on team work and team spirit;

- Employees should be made visionary to attain common goal;

- Conducive working environment should be created for employees;

- Social capital among employees and between the employees and the employer should be improved;

- Employees should be empowered to develop sense of ownership for Ambo University;

- Employees should be job secured and promoted based on merits;

- Participatory decision making should be more practiced in Ambo University; and

- Employees should be trained on work ethics and equipped with ethical values.

Employees' suggestions to increase promotion of democracy throughout all levels of your organization

Participants of the focus group discussions suggested the following strategic measures to increase promotion of democracy in all management levels of Ambo University:

- Education and trainings on principles of good governance and democratic leadership should be promoted in all management levels of the University; and

- Principles of good governance and democratic leadership should be more practiced in all management levels of Ambo University;

Employees' suggestions to improve the industrial relations of employees of Ambo University

Participants of the focus group discussions suggested the following strategic measures to improve the industrial relations of employees of Ambo University:

- The work place dispute should be minimized;

- Organizational profit from academic, research and community services should be increased;

- Environment of good will and mutual cooperation should be created; 
- Principles of good governance and democracy should be promoted in all levels of its management;

- Regular discussion forum between employees and the employer should be created to discuss on both strategic issues and solutions;

- Awareness should be created among employees on the common goals of the University;

- Participatory decision making should be more practiced in Ambo University;

- Principles of good governance and democratic leadership should be more practiced in all management levels of Ambo University;

- The University should give much focus on research and community services to increase its organizational profits through which its outreach activities may be strengthened;

- Democratic practices should be promoted through open channel of communication;

- There should be more strong public relations and democratic culture of communication among all stakeholders of Ambo University;

- Employees should be trained on principles of good governance and democratic leadership; and

- $\quad$ Strong partnership and linkage with stakeholders should be established;

\section{The perspectives of Top Management Levels of Am- bo University on Management's Strategies to Deal with Issues of Industrial Relations of Employees}

The perspectives of Administrative and development Vice President Office and academic and research vice president office of Ambo University were assessed through semi-structured interview and the results are presented hereunder.

The perspective of Administrative and development Vice President Office: The administrative and development Vice President of Ambo University was asked about the existing management strategy to minimize workplace disputes in Ambo University. Participatory discussion for conflict resolution was reported as existing management strategy to minimize workplace disputes in Ambo University.

The administrative and development Vice President of Ambo University was asked about the existing management strategy to increase organizational profits from academic, research, and community services and to create environment of good will and mutual cooperation among employees in Ambo University. Collaborative work which actively engages everyone in every decision making process with the purpose of building sense of belongingness was reported as existing management strategy to increase organizational profits from academic, research, and community services and to create environment of good will and mutual cooperation among employees in Ambo University.

The administrative and development Vice President of Ambo University was asked about the existing management strategy to promote democracy and good governance throughout all management levels of Ambo University. Working in fair, transparent, and participatory manner was reported as existing management strategy to promote democracy and good governance throughout all management levels of Ambo University.

The administrative and development Vice President of Ambo University was asked about the future plan of Ambo University to improve industrial relations of its employees, other organizations and industries. He reported that the University had, it does have, and will continue to have plan to improve industrial relations of its employees, other organizations and industries to effectively continue contributing for the sustainable development of Ethiopia.

The Perspective of academic and research vice president office: The academic and research Vice President of Ambo University was asked about the existing management strategy to minimize workplace disputes in Ambo University. Regular meeting and team work were reported as existing management strategy to minimize workplace disputes in Ambo University.

The academic and research Vice President of Ambo University was asked about the existing management strategy to increase organizational profits from academic, research, and community services. Providing quality education, furnishing necessary resources for teaching, research, and community services, and enhance community participation were reported as existing management strategy to increase organizational profits from academic, research, and community services.

The academic and research Vice President of Ambo University was asked about the existing management strategy to create environment of good will of employees and mutual cooperation among employees in Ambo University. Proper implementations of business process reengineering, balanced scorecard, and kaizen management philosophy, and team work were reported as the existing management strategy to create environment of good will of employees and mutual cooperation among employees in Ambo University.

The academic and research Vice President of Ambo University was asked about the existing management strategy to promote democracy and good governance throughout all management levels of Ambo University. Participatory approach, and working with accountability and full responsibility were 
reported as existing management strategy to promote democracy and good governance throughout all management levels of Ambo University.

The academic and research Vice President of Ambo University was asked about the future plan of Ambo University to improve industrial relations of its employees, other organizations and industries. Visiting nearby industries, exchange of human resources with other organizations, and establishing strong partnerships with international organizations through the Ethiopian Ministry of Education were reported as the major plans of Ambo University to improve industrial relations.

\section{Discussion}

\section{Problems of Industrial Relation of Employees of Ambo University}

$56.9 \%$ of the respondents voted for limitted good will of employees and mutual cooperation among employees as a problem of industrial relations in Ambo University. 60.3\% $(n=70)$ of the respondents voted for moderate extent of workplace disputes in Ambo University. 60.3\% ( $n=70)$ of the respondents voted for moderate extent of organizational profits from academic, research, and community services. $65.5 \%(n=76)$ of the respondents voted for moderate extent of good will of employees and mutual cooperation among employees in Ambo University. $62.9 \%(n=73)$ of the respondents voted for moderate extent of promotion of democracy in all management levels of Ambo University.

The aforementioned major findings of the study confirmed the existence of work place disputes, limited organizational profit from academic, research and community services, limited environment of good will and mutual cooperation, and limited promotion of good governance and democracy in all levels of Ambo University as the major contemporary problems of industrial relations of employees in Ambo University.

The existence of workplace disputes at workplaces in Ambo University complies with the findings of scholars of industrial relations of employees in service providing organizations. Workplace disputes like conflicts have impacts on organizations ranging from the disruption of relationships in the workplace and negative impacts on productivity to legal disputes that may expose the organization to significant liability (Harnois \& Gabriel, 2000; USDA, 2001; Kaufman, 2012; Work safe Victoria, 2012; Colvin, 2013; Safe Work Australia, 2013; Bonet, 2014). According to Coates et al. (1997), conflict is a form of competitive behaviour involving actual or perceived differences in interests or limited resources. Conflict can manifest itself in several ways in organizations: through disputes in the form of grievances, disciplinary actions, complaints, lawsuits, strikes, or threatened legal action; competition between colleagues or work units; sabotage; inefficiency or a lack of productivity; low morale and motivation; and withholding knowledge (Coates et al.,1997; Kaufman, 2012; Colvin, 2013; Bonet, 2014).

The existence of low organizational profits from academic, research, and community services in Ambo University comply with the findings of scholars of industrial relations of employees in service providing organizations. For instance, Sparks et al. (2001) attest that organizations may suffer financially from heightened employee perceptions of job insecurity due to the associated costs of increased absenteeism and sickness resulting from lowered employee wellbeing. Moreover, perceived job insecurity may impact on organizations in terms of less employee organizational commitment and lowered morale and motivation (Coates et al., 1997; Sparks et al.,2001).

The existence of limitted good will of employees and mutual cooperation among employees in Ambo University comply with the findings of scholars of industrial relations of employees in service providing organizations. For example, Knack \& Keefer (1997) affirm that economic activities that require some agents to rely on the future actions of others are accomplished at lower cost in higher-trust environments. On the other hand, low trust can discourage innovation. For instance, if entrepreneurs must devote more time to monitoring possible malfeasance by partners, employees, and suppliers, they have less time to devote to innovation in new products or processes (Coates et al., 1997; Knack \& Keefer, 1997; Woolcock, 1998).

The existence of limitted promotion of democracy in all levels of management in Ambo University comply with the findings of scholars of industrial relations of employees in service organizations. Corruption is economically wasteful, politically destabilizing, and destructive of governmental capacity (Nye, 1967; Ely \& Thomas, 2000; Alvesson \& Sveningsson, 2003; Jackson \& Muellenborn, 2013). Paying attention to differences in power and status is critical for understanding diversity in organizations (Ely \& Thomas, 2001; Lipsky et al., 2013). In other words, diversity increases the available pool of resources-networks, perspectives, styles, knowledge, and insights-that people can bring to bear on complex problems. For instance, traditionally underrepresented people, such as women and people of color, may have immense contributions to offer work groups. Moreover, group diversity and group outcomes have strong link which may be manifested in the potential contributions that diverse groups have to offer rela- 
tive to those that are more homogeneous (Ely \& Thomas, 2001; Lipsky et al., 2013).

\section{Management's Response to Problems of Industrial Relations in Ambo University}

Majority of the respondents (81\%) agree that the current management of Ambo University positively reacts to deal with work place disputes. Majority of the respondents $(77 \%)$ agree that the current management of Ambo University positively reacts to increase organizational profits from academic, research, and community services. Majority of the respondents (76\%) agree that the current management of Ambo University positively reacts to create environment of good will of employees and mutual cooperation among employees. Majority of the respondents (79\%) agree that the current management of Ambo University positively reacts to promote democracy in all management levels.

Scholars of industrial relations recommend effective conflict management system to deal with conflicts like workplace disputes in organizations. For instance, Coates et al. (1997) and Posthuma (2010) attest that effective conflict management systems can contribute to an effective high-performance workplace by improving employee involvement, morale, and productivity. These systems are expected to address a few key principles. First, it should accept that conflict will occur. Second, stakeholders must know that there is a clear system for managing conflict. Third, the system should address the interests of all stakeholders and should be fair and be seen to be fair. Finally, it should be easily accessible and safe to use (Coates et al., 1997; Colvin, 2013). Colvin (2013) also asserts that organizations must have strong incentives to develop procedures to manage conflict and help resolve disputes that arise in the workplace. Conflict management systems and employee voice mechanisms have been shown to improve employee involvement, commitment, and trust, as well as morale and productivity (Coates et al., 1997; Posthuma, 2010; Work safe Victoria, 2012; ACAS, 2013; Colvin, 2013; Safe Work Australia, 2013). There are five key foundational principles that any conflict management system must address: Acknowledge and accept that conflict will occur, Stakeholders need to know that there is a 'system' for conflict management, the interests of all stakeholders must be addressed, the system must be fair, and be seen to be fair, and a good conflict management system will be easily accessible and safe to use (Coates et al., 1997).

Scholars of industrial relations attest that organizations have to make sustainable business profit. For instance, Coates et al. (1997) identified efficiency gains, lower turnover, better employee-employer re- lations, potential for a better bottom line, access to information, participation in decision making, discretion over work processes, enhanced employability, support for family responsibilities, affirmation of an independent voice for workers, and input into a range of workplace issues as benefits of high organizational performance for organizations, employees, and unions. In a competitive environment in which organizations must be faster, learner, provide better service, be more efficient, and ultimately more profitable, an empowered, and proactive workforce is thought to be essential (Corsun \& Enz, 1999). In other words, the manager-employee relationship be altered in service industries to reflect the impact of the relationship between service workers and customers. Moreover, an empowered workforce is better able to provide high quality customer service. Thus, a source of competitive advantage capable of differentiating an organization from others is its people and how they work (Coates et al., 1997; Corsun \& Enz, 1999; Posthuma, 2010; ACAS, 2013; Colvin, 2013).

Scholars of industrial relations assert that a healthy workplace is a place where everyone works together to achieve an agreed vision for the health and well-being of workers and the surrounding community. They also contend that healthy workplace provides all members of the workforce with physical, psychological, social and organizational conditions that protect and promote health and safety. They also affirm that it enables managers and workers to increase control over their own health and to improve it, and to become more energetic, positive and contented (Sparks et al.2001; Burton, 2010; Dibben \& Williams, 2012; Linz \& Semykina, 2012; Snape\&Redman, 2012).

Several factors at a workplace can promote employees' psychosocial well-being and mental health. Especially important in this respect is the opportunity to be included in planning and carrying out activities and events in the workplace (e.g. the opportunity to decide and act in one's chosen way and the potential to predict the consequences of one's action). A related feature is the degree to which the environment encourages or inhibits the utilization or development of skills. Physical security, opportunity for interpersonal contact, and equitable pay are also important (Lincoln \& Kalleberg, 1985; Harnois \& Gabriel, 2000). Moreover, organizations need to be fully aware of cultural differences in work values, dress code and religion, together with potential problems in communications due to differing proficiencies in the native language used in the organization (Sparks et al., 2001). Diversity management is a management concept which emphasizes the value of difference among people in organizations (Ely \& Thomas, 2001; Kamp \& Hagedorn-Rasmussen, 2004). Diversity 
management calls on managers to take advantage of a diverse workforce in order to create sustainable competitive advantage. In other words, looking at the language of diversity management, 'the quest for talents', where every organization should ensure the access of talented people of whatever colour, religion, gender, etc, is persevering (Ely \& Thomas, 2001; Kamp \& Hagedorn-Rasmussen,2004).

Some scholars also encourage environment of goodwill and mutual cooperation. For instance, Woolcock (1998) contends that social capital's greatest merit is that it provides a credible point of entry for socio-political issues into a comprehensive multiand interdisciplinary approach to some of the most pressing issues of our time. In other words, trusting societies not only have stronger incentives to innovate and to accumulate physical capital, but are also likely to have higher returns to accumulation of human capital. Moreover, trust and norms of civic cooperation are essential to well-functioning societies, and to the economic progress of those societies (Coates et al., 1997; Knack \& Keefer, 1997; Woolcock, 1998; Ely \& Thomas, 2001; Marchington \& Suter, 2013).

Trust-sensitive transactions include those in which goods and services are provided in exchange for future payment, employment contracts in which managers rely on employees to accomplish tasks that are difficult to monitor, and investments and savings decisions that rely on assurances by governments or banks that they will not expropriate these assets (Knack \& Keefer, 1997). For instance, individuals in higher-trust societies spend less to protect themselves from being exploited in economic transactions and written contracts are less likely to be needed, and they do not have to specify every possible contingency. Moreover, individuals in high-trust societies are also likely to divert fewer resources to protecting themselves-through tax payments, bribes, or private security services and equipment-from unlawful (criminal) violations of their property rights (Coates et al., 1997; Knack \& Keefer, 1997; Woolcock, 1998). Furthermore, societies characterized by high levels of trust are also less dependent on formal institutions to enforce agreements (Knack \& Keefer, 1997).

Scholars of industrial relations encourage promotion of good governance and democracy throughout all levels of organizations. For instance, Jackson \& Muellenborn (2013) assert that institutions serve to coordinate action because they have interpretative meaning to actors. In particular, value-rational aspects of institutions provide interpretive frames for actors to judge the legitimacy of actions and thereby mobilize efforts to enforce institutionalized rules and norms (Alvesson \& Sveningsson, 2003). Another case in point is that of Musso et al. (2000) and Alvesson \& Sveningsson(2003) who contend that the function of leadership is to create change as leadership creates new patterns of action and new belief systems.

Empowerment can have a significant impact on a broad range of important outcomes in many organizational contexts. Empowerment is associated with job satisfaction, managerial effectiveness, creativity, and team performance and negatively related to strain and turnover intentions. Moreover, empowerment is the strongest predictor of organizational productivity (Corsun \& Enz, 1999; Nalbandian, 1999; Raub \& Robert, 2010). Empowering leadership had a robust relationship with both in-role and affiliative extrarole behaviors, and indirectly with challenging extrarole behaviors via psychological empowerment (Alvesson \& Sveningsson, 2003; Raub \& Robert, 2010).

An important aspect of a good empowerment program, particularly in societies where managers are not traditionally challenged, debated, or questioned, might be training for leaders on how to work constructively with subordinates who engage in challenging behaviors. Moreover, managers need to ensure that the empowering behaviors demonstrated by leaders align with needs that high power values employees have for achieving power (Stoker, 2006; Raub \& Robert, 2010; Bonet, 2014). To improve the chances of success in structural empowerment efforts, supportive and helping relationships should be develped. Co-workers, customers, and would do well to express and model supportive and helping behaviours. As these values come to be shared and lived, the quality of work and service provided are likely to increase among employees (Lincoln \& Kalleberg, 1985; Corsun \& Enz, 1999).

Public value management does offer a new paradigm and a different narrative of reform. Its strength lies in its redefinition of how to meet the challenges of efficiency, accountability, and equity and in its ability to point to a motivational force that does not rely on rules or incentives to drive public service reform. It rests on a fuller and rounder vision of humanity than does either traditional public administration or new public management. People are, it suggests, motivated by their involvement in networks and partnerships, that is, their relationships with others formed in the context of mutual respect and shared learning (Stoker, 2006; Bonet, 2014).

\section{Conclusion}

The problems of industrial relations of employees of Ambo University reported were: limitted good will and mutual cooperation; limitted promotion of democracy in all levels of management, limitted organizational profits from academic, research, and 
community services and work place disputes. Majority of the respondents agree that the current management of Ambo University positively reacts to deal with work place disputes, increase organizational profits from academic, research, and community services, create environment of good will of employees and mutual cooperation among employees, and promote democracy in all its management levels. In conclusion, Ambo University will have a better prospect for industrial relations of its employees if the institution carefully implement the strategic measures proposed in this study. Based on the findings of the study the following strategic recommendations are proposed:

- Promoting good governance in all levels of the organization to fight corruption and bad governance;

- Establishing appropriate reward and incentive mechanisms for employees;

- Creating favorable working environment for employees and environment of good will and mutual cooperation among employees;

- Strengthening more collaboration and partnerships with other organizations at all levels;

- Undertaking academic, research, and community services on demand driven development issues of local communities and industries;

- Motivating employees for hard work and promotion of cultural relativism;

- Experience sharing among employees;

- Periodical discussion on issues of industrial relations between the management and employees;

- Promoting new innovations and providing incentives for new innovations development;

- Encouraging employees to use modern technologies like ICTs in service delivery.

- The work place dispute should be minimized;

- Organizational profit from academic, research and community services should be increased;

- Principles of good governance and democracy should be promoted in all levels of its management;

- Regular discussion forum between employees and the employer should be created to discuss on both strategic issues and solutions;

- Awareness should be created among employees on the common goals of the University;

- Participatory decision making should be more practiced in Ambo University;

- Principles of good governance and democratic leadership should be more practiced in all management levels of Ambo University;

- The University should give much focus on research and community services to increase its organizational profits through which its outreach activities may be strengthened;

- Democratic practices should be promoted through open channel of communication;

- There should be more strong public relations and democratic culture of communication among all stakeholders of Ambo University;

- Employees should be trained on principles of good governance and democratic leadership; and

- Strong partnership and linkage with stakeholders should be established.

\section{References}

Advisory, Conciliation, and Arbitration Service (ACAS). 2013. Mediation: an approach to resolving workplace issues [online]. London: ACAS. Available at: www.acas.org.uk/mediation [Accessed 24 July, 2015].

Ambo University. 2015. Balanced Score Card (BSC) document. (Unpublished).

Ambo Town Administration Office. 2013. Profile of Ambo Town (Unpublished).

Alvesson,M, and Sveningsson, S.2003. Managers doing leadership: The extra-ordinarization of the mundane. Human Relations 56(12): 1435-1459.

Ambo Town Administration Office. 2013. Profile of Ambo Town (Unpublished).

Bonet, R. 2014. High-Involvement Work Practices and the Opportunities for Promotion in the Organization. Industrial relations, Vol. 53, No. 2:295-324.

Burton, J. 2010. WHO Healthy Workplace Framework and Model: Background and Supporting Literature and Practices.

Castilla,E.J. 2012. Gender, Race, and the New (MeritBased) Employment Relationship. Industrial relations, Vol. 51, No. S1:528-562.

Coates,M.L., Furlong,G.T and Downie,B.M.1997. Conflict management and dispute resolution systems in Canadian nonunionized organizations.Kingston, Kingston, Ontario,Canada: Queen's University Industrial Relations Centre (IRC).

Colvin, A.J.S.2013. Participation Versus Procedures in Non-Union Dispute Resolution Dispute Resolution. Industrial relations, Vol. 52, No. S1:259-283.

Corsun,D.L., and Enz,C.A.1999. Predicting Psychological Empowerment Among Service Workers: The Effect of Support-Based Relationships. Human Relations, 52: 205-224.

Dibben, P and Williams,C.C.2012. Varieties of Capitalism and Employment Relations: Informally Dominated Market Economies. Industrial relations, Vol. 51, No. S1:563-582.

Ely,R.J., and Thomas,D.A.2001. Cultural Diversity at Work: The Effects of Diversity Perspectives on Work Group Processes and Outcomes. Administrative Science Quarterly, 46:229-273.

Harnois,G., and Gabriel, P.2000. Mental health and work: Impact, issues and good practices. Geneva: International Labour Organisation. 
Jackson,G. and Muellenborn,T.2012. Understanding the Role of Institutions in Industrial Relations: Perspectives from Classical Sociological Theory. Industrial relations, Vol. 51, No. S1: 472-500.

Kamp,A., and Hagedorn-Rasmussen,P.2004. Diversity Management in a Danish Context: Towards a Multicultural or Segregated Working Life? Economic and Industrial Democracy, Vol. 25(4): 525-554.

Kaufman,B.E. 2012. An Institutional Economic Analysis of Labor Unions. Industrial relations, Vol. 51, No. S1:438-471.

Kelly,R.M. 1998. An inclusive democratic polity, representative bureaucracies, and the new public management. Public Administration Review, Vol. 58, No. 3: 201-208.

Knack,S., and Keefer,P.1997. Does social capital have an economic payoff? A cross-country investigation. The Quarterly Journal of Economics, Vol. 112, No. 4:1251-1288.

Lincoln,J.R.,and Kalleberg, A.L.1985. Work Organization and Workforce Commitment: A Study of Plants and Employees in the U.S.and Japan. American Sociological Review, Vol. 50, No. 6:738-760.

Linz, S.J., and Semykina, A. 2012. What Makes Workers Happy? Anticipated Rewards and Job Satisfaction. Industrial relations, Vol. 51, No. 4:811-844.

Lipsky, D.B, Lamare,J.R., and Gupta,A.2013. The effect of gender on awards in employment arbitration cases: The experience in the securities industry. Industrial Relations, Vol. 52, No. S1:314:342.

Marchington,M., and Suter,J. 2013. Where informality really matters: patterns of employee involvement and participation (EIP) in a non-union firm. Industrial Relations, vol. 52, no. s1:284-313.

Marsden, D.2013. Individual Voice in Employment Relationships: A Comparison under Different Forms of Workplace Representation. Industrial relations, Vol. 52, No. S1:221-258.

Musso,J., Weare,C., and Hale,M. 2000. Designing Web Technologies for Local Governance Reform: Good Management or Good Democracy? Political Communication, 17, 1: 1-19.

Nalbandian,J. 1999. Facilitating Community, Enabling Democracy: New Roles for Local Government Managers. Public Administration Review, Vol. 59, No. 3: 187-197.
Nye, J.S. 1967.Corruption and Political Development: A Cost-Benefit Analysis. The American Political Science Review, Vol. 61, No. 2 :417-427.

Posthuma, R.A. 2010. Employee and labor relations Instructor's manual: Workplace dispute resolution. Alexandria, USA: Society for Human Resource Management.

Raub,S., and Robert,C. 2010. Differential effects of empowering leadership on in-role and extra-role employee behaviors: Exploring the role of psychological empowerment and power values. Human Relations, 63: $1743-1770$

Safe Work Australia. 2013. Guide for preventing and responding to workplace bullying. Available at: www.swa.gov.au (Accessed 24 July, 2014).

Shanmugham, S., and Tekele, S.B. 2011. An Assessment on the Status of Water Supply and Sanitation In Ethiopia: A Case of Ambo Town. Journal of Sustainable Development in Africa,13, No.1.

Snape, E.D., and Redman,T. Industrial relations climate and union commitment: an evaluation of workplacelevel effects. Industrial Relations, Vol. 51, No. 1:1128.

Sparks,K., Faragher,B., and Cooper,C.L.2001. Well-being and occupational health in the 21st century workplace. Journal of Occupational and Organizational Psychology, 74:489-509.

Stoker,G. 2006. Public Value Management: A New Narrative for Networked Governance? The American Review of Public Administration,36 (1): 41- 57.

United Nations Human Settlements Programme (UNHABITAT). 2008. Ethiopia: Ambo Urban Profile. Nairobi : UN-HABITAT.

United States Department of Agriculture (USDA).2001. The USDA handbook on workplace violence prevention and response. AD-1135.

Woolcock., M. 1998. Social capital and economic development: Toward a theoretical synthesis and policy framework. Theory and Society, 27: 151-208.

WorkSafe Victoria. 2012. Your guide to Workplace bullying - prevention and response. Melbourne, Australia: WorkSafe Victoria.

Yamane, Taro. 1967. Statistics: An Introductory Analysis, $2^{\text {nd }}$ Ed., New York: Harper and Row. 